International Journal of Linguistics, Literature and Translation

ISSN: 2617-0299 (Online); ISSN: 2708-0099 (Print)

DOI: 10.32996/ijltt

Journal Homepage: www.al-kindipublisher.com/index.php/ijltt

\title{
Attitudes of EFL College Students of the University of Bisha towards eLearning
}

\author{
Almaqtri Mahmoud Ahmad Thabet 8 (D) \\ Associate Professor of Applied Linguistics, Department of English, College of Sciences and Arts (An-namas), University of Bisha, \\ KSA; Department of English, College of Arts, Ibb University, Ibb, Yemen \\ $\triangle$ Corresponding Author: Almaqtri Mahmoud Ahmad Thabet, E-mail: maktram@gmail.com
}

ARTICLE INFORMATION ABSTRACT

Received: August 06, 2021

Accepted: September 15, 2021

Volume: 4

Issue: 9

DOI: $10.32996 /$ ijllt.2021.4.9.12

\section{KEYWORDS}

Attitudes, EFL College students, eLearning, preference, University of Bisha
This study aimed to find out the attitudes of the EFL College students of the University of Bisha, Saudi Arabia, towards elearning after they have studied via this mode for almost two semesters. The study tried to answer four questions related to the participants' preferences of learning mode, the reasons for their preference, the problems with eLearning, and gender differences. Three null hypotheses related to the first three questions referred to above were postulated regarding gender differences if any. The study was mainly quantitative, in which data were collected by means of an online questionnaire administered to $148 \mathrm{EFL}$ students (males and females) who were selected from the target population purposively. The SPSS program (version 20.0) was used to analyze the obtained data. We have found that the majority of participants had positive attitudes to eLearning, and they preferred it to the face-to-face classroom-based mode. Among the reasons they offered for their preference elearning were their claims that they learned better than with face-to-face mode. In addition to flexibility, this mode saved time, cost and effort, since the students took activities and assessments at home, not at college. All three given hypotheses were accepted in that no gender difference was found.

\section{Introduction}

E-learning _the vogue of the time _is considered as one of the best modes of instruction, if not the only one among the teaching/learning modes these days (Arkorful \& Abaidoo, 2015). Though eLearning has been used for sometimes, as a tool supporting the classroom traditional mode, it is the imminent need necessitated by the spread of the covid-19 pandemic, which required the transition to this mode as the only option available (Mahyoob, 2020). Therefore, as in many other countries across the globe, all educational institutions in Saudi Arabia had to close the doors of their buildings and turn to this mode. This happened with all institutions including schools and universities. The English departments were no exception. After the students were exposed to this type of instruction for almost three semesters, it is not clear what was their perception about it. It is not clear whether the EFL students like it or not. Therefore, it is the purpose of this study to find out the EFL students' attitudes to eLearning. This can be through answering the following questions: Do the EFL college students prefer eLearning to face-to-face mode? If they do, what reasons do they give for their preference? What kind of problems or difficulties have participants encountered with eLearning? Is there a gender difference in the preference of the mode of learning, reasons for preference, or difficulties faced? These are the questions, which this paper sought to explore in the following pages.

\subsection{Objectives of the Study}

This study aimed at

1. Identifying the participants' preference of the mode of learning: eLearning or face-to-face.

2. Finding out the reasons they gave for their preference of the mode of learning.

3. Identifying the problems with eLearning from the participants' perspective.

4. Probing if there were significant differences between males and females in items one to three above.

\begin{tabular}{ll|l} 
K & C AL-KINDI CENTER \\
$\mathbf{R}$ & $\mathbf{D}$ & FOR RESEARCH AND
\end{tabular} $\mathbf{R}$ D FEVELOPMENT Your gateway to world-class research

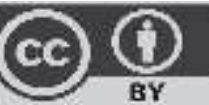

Published by Al-Kindi Center for Research and Development, London, United Kingdom. Copyright (c) the author(s). This open access article is distributed under a Creative Commons Attribution (CC-BY) 4.0 license 


\subsection{The Significance of the Study}

By identifying the attitudes of the target students to eLearning and their preference of the learning mode, policymakers, course planners and curricular designers could take the appropriate decisions regarding implementing the type of teaching/learning mode and the degree to which they can recommend how best to use it and how to avoid its adverse effects. Accordingly, instructors can also take the correct measures to make the best of this mode in when, what, how, and how much to use it and be in line with the students' preferences.

\subsection{The Study Questions}

This study was going to find answers to the following questions:

1. What mode of learning did the participants prefer: eLearning or face-to-face?

2. What reasons did the participants give for their choice of the preferred mode?

3. What problems did eLearning have from the participants' perspectives?

4. Was there any difference between males and females in respect of the three questions above? If 'yes' how significant was the difference?

\subsection{The Hypotheses}

It is hypothesized that there were no significant differences between males and females regarding the:

a. Preferences of the mode of learning.

b. Reasons for preferring the mode of learning.

c. Problems with eLearning

\subsection{Operational Definitions of Terms}

'Attitude' was taken to mean the ELT students' opinion at the University of Bisha about eLearning after being exposed to it for about two academic semesters.

'ELearning' here stood for the instructional process of teaching and learning conducted online by using appropriate technology such as mobiles and computers.

'Preference' meant the participants' decision to choose between either eLearning or face-to-face as the preferred mode of learning.

'Problem' stood for the difficulties and drawbacks that eLearning had, as expressed by the participants.

\section{Literature Review}

Libraries and databases are not short of the relevant literature on the topic of the students' attitudes to and satisfaction with elearning. Many studies on the topic are available. However, none has touched on the topic with these specific types of students at this particular University of Bisha, Saudi Arabia. In the following paragraphs, we are going to shed some light on some of these studies under three subheadings: 1 . Students' satisfaction with eLearning, 2. Advantages of eLearning and 3. Disadvantages of eLearning. All the three subheadings will be tackled from the students' perspectives.

\subsection{Students' Satisfaction with eLearning}

Institutions, educational ones, in particular, seek quality in the performance of their programs. Knowing whether quality performance is achieved or not can take different forms which can be direct or indirect; direct are like tests, assignments projects, products and so on. Indirect are those related to the satisfaction of the stakeholders through survey questionnaires or interviews (Tesema et al., 2017). In this study, the indirect method used was a questionnaire. This may show how satisfied the participants were with elearning. Several studies have dealt with students' satisfaction similar to our situation.

One of these studies is conducted at Taibah University in Saudi Arabia, on the analysis and evaluation of eLearning and its impact on the university students' satisfaction; it has been found that the students were highly satisfied with elearning in its three dimensions: faculty members, distance education process and infrastructure. As with a number of other studies on tertiary students' satisfaction with elearning, this study also confirms the results found in our study in that the students have been found satisfied with eLearning mode (Alqadah, 2021).

Mahyoob (2020), in one of his research questions, in a study conducted in Saudi Arabia, discusses the learners' satisfaction with online learning during the pandemic of covid-19. The result shows that $43.20 \%$ of the learners are satisfied with online learning, whereas $42.90 \%$ are somehow satisfied with some reservations. About $13.80 \%$ of learners are not happy with online learning. In other words, the majority (86.1\%) are satisfied with eLearning. This result is in agreement with the findings of the study in hand. 
Earlier, Faqeeh (2011) carried out a study with ELT undergraduate students at King Abdullah University, again in Saudi Arabia. The students are asked if they want to use the eLearning as a learning mode, and if they accept to perform learning activities through this mode. It is concluded that the students are well prepared to use the eLearning mode of instruction. This indicates that the students are satisfied with this type of learning.

In a descriptive-analytical study (Sir elkhatim et at., 2021) in the Saudi context with students of English, about the effect of elearning on students' knowledge management and how knowledge is acquired through the different techniques used in elearning, and if the students are aware of this process. The most important results are that elearning instructional techniques keep up with the quality development in the educational process with students' agreement $83.3 \%$; such techniques help in presenting the subject matter better than that of the traditional face-to-face ones with agreement $70.1 \%$; they help in developing creative thinking $75.2 \%$. Besides enhancing students' motivation to learn, they help in better interaction and communication $74.8 \%$. Whether elearning develops creative, critical thinking or motivation needs to be searched in our case. Regarding interaction, during the two semesters in teaching online, we found little interaction among or our students compared with face-to-face learning. The real presence of both instructor and students in the classroom makes interaction easier.

Another study by Al-Samarraie et al. (2017) aimed to identify the factors that affect students and teachers' satisfaction with elearning. The researchers used a systematic literature review for this purpose. The study reveals that both instructors and students are satisfied with elearning instruction at university and college levels. The students, in particular, were in favors of continuing using this mode of instruction.

Apart from the Saudi context, Abduljawad, et al. (2020) try to examine the factors that affect the acceptance of eLearning at Jordanian universities. They do that by evaluating the students' satisfaction. It is found that a vast majority of the targeted participants were satisfied with using eLearning. However, in Iraq, another study indicates that using eLearning is not free from drawbacks and difficulties (Al-Jubori et al., 2021). In this latter study, the researchers find that some factors that affect successful eLearning and motivation to learn the language. It is motivation that plays an important role in the success of any learning system, including eLearning (Prasetyo et al., 2021). They add that students' satisfaction is mainly related, besides motivation, to the availability of the required technology and the ability of the institutions to provide that technology. In Saudi Arabia, technology has never been a problem not only at colleges but at schools too. This claim is confirmed by Algahtani's (2011). The Saudi government has succeeded in solving the problem and filling the gap at the start of the covid-19 pandemic within a short period.

In departments and majors other than English, medical students' satisfaction was negative. In one study, the results show that the students are not much satisfied with eLearning instruction. In other words, the conventional classroom is much more effective and superior (Kaur et al., 2020). Lack of technology and its use plays a major role in this negative attitude. However, we should be careful here as in some countries, unlike the case in Saudi Arabia, problems of providing the required technology were prevalent. This will necessarily affect students' satisfaction with eLearning.

\subsection{Advantages of eLearning}

Different studies reported that the advantages of eLearning excel those of its disadvantages and are far much better than those of traditional learning are. These advantages are saving time, space, effort, and cost (Abduljawad, et al. 2020; Mahyoob, 2020; Arkorful, \& Abaidoo, 2015; Schreurs, et al., 2008; Aydin, \& Tasci, 2005). It is also flexible and can be used in different circumstances and situations (Mohammed, \& Mohamed, 2021). eLearning is flexible because students can take or join sessions at their convenience whether synchronous or synchronous and whenever and wherever they are at home or even in their cars, lying on the bed or walking in the street and so on, providing 24-hour-a-day accessibility to different materials and activities (Abouchedid, \& Eid, 2004). Another advantage is the benefit of recording the sessions so that the students can refer back to the recordings of sessions any time anywhere they like. Add to these advantages is the ease of accessing the lecture recordings and accessing other relevant materials (Aydin \& Tasci, 2005). In addition, ELearning helps increase learners' retention and understanding of the subject matter due to the different techniques that eLearning provides such as quizzes, assignments, discussions, videos and many more (Omaret et al., 2012).

The ability to pay attention to the individual learners and their needs is another advantage (Arkorful, \& Abaidoo, 2015; Marc, 2002). This element has been neglected in traditional classroom instruction. The idea of focusing on the individual student is useful, as this will help to provide the necessary support to each one. The instructors can then tailor their teaching activities to those who need such special attention, whether they are bright or low achievers. The availability of different materials, activities, and assessments techniques that eLearning provides makes this advantage easy to fulfill.

According to Sandars and Langlois (2005) and Wheeler (2012) eLearning is accompanied with a group of other advantages such as good accessibility and availability of up-to-date information, the speed and ease of access to a wide range of resources, and 
the opportunity for the learners to work at their own pace. With the help of technology, knowledge effectively reaches out to learners easily and free from complexity. Further, online learners can have control over their own learning, and they can take active part in discussions and group work with their fellow students. Moreover, those who live in remote areas or have jobs and cannot attend regular classes can have the chance to continue their education at their doorsteps (Suerni, 2021). In short, elearning helps achieve the education objectives and fulfills the fast-changing requirement of the time (Alhudaithy, 2021).

In another semi experimental study in the Saudi context at Hail University, but with students of education and communication technology, it is found that there has been a significant indicator that elearning has improved self-learning skills due to sex variable in favor of males. The study recommends activating and using eLearning in the educational process with this type of student (Al-rashid, 2020; Suerni, 2021). Schreurs et al. (2008) claim that elearning makes it easy for the students to access the world of information and knowledge and exchange information through social media tools. Moreover, the students through eLearning are able to do their own work without others' help. However, the findings also showed students' disagreement that eLearning leads to the improvement of the quality of the teaching-learning process. The claim that students can do their work, tasks or tests without the help of others is questionable because in many cases in our situation, students have been found to depend on different means and persons to help them doing such requirements. However, the claim that students can do their work by themselves can be true with highly motivated and honest students at least in situations like ours.

\subsection{Disadvantages of elearning}

While the advantages of eLearning are undeniable and many, some researchers suspect eLearning effectiveness (Abouchedid, \& Eid, 20004). According to some studies, eLearning can pose some challenges especially to language learners. Such challenges are mainly in the major skills of writing, speaking and reading. Other challenges are in teaching phonetics and phonology, where the students have to be face to face with the instructors (Mayhoob, 2020). However, such challenges can be overcome using materials and applications such as youtube and other applications. Arkorful, \& Abaidoo (2015). claim that in elearning, the interaction between the different parties is lacking compared to that in the classroom. The students feel detached and isolated. Therefore, knowledge building that is based on interaction skills is lacking. Moreover, they think that when it comes to the idea of clarification and explanation, eLearning stops short (Bettinger et al., as cited in Kauret et al., 2020). This claim needs to be searched specially with the fast development in the E-system and technology. However, the critical defects are those related to plagiarism and cheating, which for the authors are difficult to control. Actually, we as instructors stood helpless in dealing with the students' cheating, in particular when copying from each other or seeking someone else to do the job for them in examinations or even on doing assignments online. It is clear that there is a connection between these defects and lack of motivation. Lack of motivation and readiness to learn and low level of involvement are considered factors that affect eLearning success (Mohammed, \& Mohamed, 2021; Tarhini, et al., 2013). The idea that plagiarism and cheating are an outcome of lack of motivation is undeniable, as we have experienced this with our own students; low underachievers are usually unmotivated to learn.

A number of studies have indicated that among the difficulties students have experienced are like Internet cost, slow speed of Internet or lack of effective technology, and the skills to use that technology (Kihara \& Gichoya, 2014, as cited in Abed, 2020). However, such difficulties, which are prevalent in many countries, do not apply to the Saudi context in general and the University of Bisha in particular.

Some even went to question the eLearning instructors' ability to meet the needs of their students psychologically, morally, socially, and even academically since students cannot see their instructors and vice versa. The same happens with interpersonal exchanges, which become even more difficult compared with real classroom situations (Slagter van Tryon, \& Bishop, 2012); Swanson et al., 2010) state that students at eLearning sessions do not feel connected with their instructors. Here comes the importance of blended learning to ensure that there is a predefined method of transferring idea to online students in such a way that the needs of these students are met (Kholifah et al., 2020). Students of English in eLearning mode, in particular weaker students, tend to be left behind as they are more reserved, cautious or shy compared to their more eloquent and motivated fellows (Al-Jubori et al., 2021). Then one might ask about the level of how well teachers and students are able to use the Etechnology and the different and newly emerging applications (Sukendro et al., 2020 ; Tarhini et al., 2013). However, this last point has been dealt with quite successfully in Saudi Arabia as teachers/instructors have already been using eLearning, though partially, for a considerable time. Only some extra training was required for some applications and tasks or activities. The students also are very acquainted with this technology and its various uses.

\section{The Method of the Study}

The quantitative survey method was used in this study:

The independent variables: males/females (Academic levels and type of college variables are discarded)

The dependent variables:

1. Students' preference of the mode of learning: eLearning or face-to-face 
2. The reasons for choosing either modes of learning: eLearning or face-to-face

3. Problems with eLearning from the participants' perspectives

4. Gender differences related to the three variables mentioned above

Though the quantitative method was the main method, yet some qualitative remarks were used here and there based on the field experience of the researcher.

\subsection{Data Collection}

To collect the data from the participants, an online questionnaire was designed, and the link was made available to the participants through WhatsApp groups. The sent copy was given in the students' native language_ Arabic_to make it easy for them to respond. The Questionnaire consisted of two sections: the first one was questions on the demographic data of the participants, and the second was the main body of the questionnaire, which, consisted of 29 items, categorized under three main dimensions: 1. Participants' preference with elearning (nine items); 2 . The reasons the participants gave for preferring of either mode (14 items); 3. Problems with eLearning (six items) as shown in Table 1.

Table 1: Questionnaire Dimensions and Reliability Measures

\begin{tabular}{|l|l|l|l|}
\hline The domain & Items Related & Total Dimensions & Reliability \\
\hline $\begin{array}{l}\text { Participants' preference of } \\
\text { the mode of learning }\end{array}$ & $1,9,14,15,21,24,25,26,29$ & 9 & 0.750 \\
\hline $\begin{array}{l}\text { Reasons for the preferring E- } \\
\text { Learning }\end{array}$ & $\begin{array}{l}2,3,4,5,6,7,8,12,13,16,17 . \\
19.20 .27\end{array}$ & 14 & 0.740 \\
\hline Problems with E-Learning & $10,11,18,22,23,28$ & 6 & 0.800 \\
\hline
\end{tabular}

\subsection{The Reliability and Validity of the Questionnaire}

To test the reliability of the questionnaire, the Cronbach's Alpha Based on Standardized Items test was used, and the reliability measures of the three dimensions of the questionnaire were found between 0.750 and 0.800 for all the items. (See Table 1). This means the scale was reliable as the measures were higher than 0.70 . With respect to validity, the questionnaire was given to three instructors who checked it and gave their remarks; modification was made accordingly.

\subsection{The Study Sample}

The study sample was taken from the larger population of the students studying at the English departments in three colleges affiliated with the University of Bisha, Saudi Arabia. The participants were studying online during the lockdown due to the covid19 pandemic. They came from all eight different academic levels. Many of them were those whom I taught online. The target population number from where the sample was taken was not known but can be estimated as about 450 students. The turnedout rate was 148 responses from both males and females in the three colleges.

\subsection{Sample Selection}

The study sample was selected purposively. The questionnaire link was sent online to WhatsApp groups to all those studying online in the second semester of the academic year, 2000-2021. Not all students responded to the questionnaire. Those who responded made up the sample of our study, which, consisted of 148 students: males 54(36.5\%) and females 94(63.5\%). The distribution of the sample members from the three colleges and from the eight levels is given in Table 2 according to gender. Most of the participants were from the three levels, namely five, seven and eight. This was representative of the number of the enrolled students in that semester, and as can be seen, they were fewer in levels one, two, three, four and six than those in levels five, seven, and eight.

Table 2. Participants' Distribution According to Academic Levels

\begin{tabular}{|c|c|c|c|c|}
\hline Level & Freq. & $\%$ & Valid Percent & Cum \% \\
\hline 1 & 3 & 2.0 & 2.0 & 2.0 \\
\hline 2 & 1 & .7 & .7 & 2.7 \\
\hline 3 & 7 & 4.7 & 4.7 & 7.4 \\
\hline 4 & 7 & 4.7 & 4.7 & 12.2 \\
\hline 5 & 32 & 21.6 & 21.6 & 33.8 \\
\hline 6 & 4 & 2.7 & 2.7 & 36.5 \\
\hline
\end{tabular}




\begin{tabular}{|c|c|c|c|c|}
\hline 7 & 36 & 24.3 & 24.3 & 60.8 \\
\hline 8 & 58 & 39.2 & 39.2 & \multirow{2}{*}{100.0} \\
\hline Total & 148 & 100.0 & 100.0 & \\
\hline
\end{tabular}

Cum = Cumulative Percentage; Freq = Frequency

In Table 2, most of the participants were mainly from levels five, seven and eight. This is representative of the actual number of students enrolled in these levels.

Table 3 shows participants' distribution according to gender

Table 3 Participants' Distribution According to Gender

\begin{tabular}{|c|c|c|c|c|}
\hline & Freq. & \% & Valid \% & Cum.\% \\
\hline Valid. 00 & 1 & .7 & .7 & .7 \\
\hline male & 54 & 36.5 & 36.5 & 37.2 \\
\hline female & 94 & 63.5 & 63.5 & 100.0 \\
\hline Total & 148 & 100.0 & 100.0 & \\
\hline
\end{tabular}

Cum = Cumulative percentage; Freq = Frequency

In Table 3 females are almost as double as males are. This reflects the normal distribution of students where girls are more than boys in the English departments.

Table 4 presents participants' distribution according to college

Table 4 Participants' Distribution According to College

\begin{tabular}{|c|c|c|c|c|}
\hline City & Frequency & Percent & Valid Percent & Cum. Percent \\
\hline An-namas & 39 & 26.4 & 26.4 & 26.4 \\
\hline Balqarn & 38 & 25.7 & 25.7 & 52.0 \\
\hline Bisha & 69 & 46.6 & 46.6 & 98.6 \\
\hline Other & 2 & 1.4 & 1.4 & 100.0 \\
\hline Total & 148 & 100.0 & 100.0 & \\
\hline
\end{tabular}

Table 4 shows that participants from the College of Arts in Bisha are more than they are in the other colleges and this is because this college is located in the main campus of the University of Bisha.

\subsection{The Pilot Study}

The questionnaire was tested on 50 students of both genders and was sent to them online through the WhatsApp groups. The return rate was 48 responses. The necessary modifications were made to ensure ease for understanding.

\subsection{Data analysis}

To analyze the collected data, both descriptive and inferential statistics measures were used. Descriptive statistics like frequency and percentage were used to measure, for example, the number of males and females in the sample, and the responses for each item. With respect to the inferential statistics measures, the independent-samples t-test (Pallant, 2010) was used to compare the mean score of the dependent variables and find out if there were significant differences between males and females in the three dimensions: students' preference of mode with eLearning, reasons for preferring one mode to the other, and problems with eLearning. The SPSS package version 20.0 was used for this purpose.

\section{Findings}

The findings of the study are presented in relation to each study question as follows:

Question1: Which mode of learning did the participants prefer: eLearning or face-to-face?

To answer Question 1, Table 5 shows the descriptive statistics: Frequency and percentage for both males and females regarding the preferred mode. 


\begin{tabular}{|c|c|c|c|c|c|}
\hline \multirow[t]{2}{*}{ Item No. } & \multirow{2}{*}{ Item } & \multicolumn{2}{|c|}{ Agree } & \multicolumn{2}{|c|}{ Disagree } \\
\hline & & Freq. & $\%$ & Freq. & $\%$ \\
\hline 1. & ELearning is better that face-to-face & 100 & 67.6 & 23 & $16 \%$ \\
\hline 9. & I learn better via eLearning than with face-to-face & 90 & 61 & 22 & 15 \\
\hline 14 & Face-to-face learning in classroom is better. & 33 & 22.3 & 69 & 46.6 \\
\hline 15 & $\begin{array}{l}\text { I prefer eLearning to face-to-face even though I get low } \\
\text { grades }\end{array}$ & 58 & 39.2 & 61 & 41.2 \\
\hline 21 & $\begin{array}{l}\text { If given a choice, I will choose the face-to-face learning } \\
\text { mode }\end{array}$ & 32 & 22 & 83 & 56.4 \\
\hline 24 & Instructors prefer eLearning & 78 & 52.7 & 32 & 22 \\
\hline 25 & $\begin{array}{l}\text { Students' involvement in eLearning is better than in } \\
\text { face-to-face }\end{array}$ & 110 & 74.3 & 20 & 16 \\
\hline 26 & $\begin{array}{l}\text { I believe that eLearning should be used only in cases of } \\
\text { emergencies }\end{array}$ & 92 & 62.2 & 40 & 27 \\
\hline 29 & I recommend a full use of eLearning mode in future & 83 & 56.1 & 27 & 18 \\
\hline
\end{tabular}

Table 5: Participants' Responses of the Preferred Mode

To test hypothesis A and find out if there was a significant difference between males and females regarding their preference of the mode of learning, an independent-samples t-test was conducted for this purpose. The result showed that there was no significant difference in scores for males $(M=29.21, S D=10.32)$ and females $(M=30.33, S D=4.5 ; t(143)=1.524-, p=.13$, twotailed).

As can be seen, the $p$ value is larger than 0.5 ( $p>0.5$ ), which means there was no difference between males and females. Therefore, hypothesis A was accepted in that there was no difference between males and females in their preference of eLearning over face-to-face mode.

Question 2: What reasons did the participants give for their preference of the preferred mode?

The answer to this question is given in Table 6 in frequency and percentage.

Table 6: Reasons for Preferring Mode of Learning

\begin{tabular}{|c|c|c|c|c|c|}
\hline \multirow{2}{*}{ Item NO } & \multirow{2}{*}{ Item } & \multicolumn{2}{|c|}{ Agree } & \multicolumn{2}{|c|}{ Disagree } \\
\hline & & Freq. & $\%$ & Freq. & \\
\hline 2 & $\begin{array}{l}\text { I prefer eLearning to scape attending classes at } \\
\text { college }\end{array}$ & 63 & 43 & 23 & 16 \\
\hline 3 & $\begin{array}{l}\text { I prefer eLearning because exams are taken outside } \\
\text { at college }\end{array}$ & 85 & 57.4 & 41 & 28 \\
\hline 4 & I prefer elearning because it saves time & 123 & 83.11 & 16 & 11 \\
\hline 5 & I prefer eLearning because it saves effort & 109 & 74 & 24 & 16 \\
\hline 6 & $\begin{array}{l}\text { I prefer eLearning to avoid participation in } \\
\text { classroom }\end{array}$ & 36 & 24 & 96 & 65 \\
\hline 7 & I prefer eLearning because I get higher grades & 72 & 49 & 57 & 39 \\
\hline 8 & In elearning I feel free to move & 125 & 85 & 8 & 5.4 \\
\hline 12 & $\begin{array}{l}\text { I prefer eLearning for the advantage of writing using } \\
\text { the chat tool }\end{array}$ & 122 & 82.4 & 17 & 12 \\
\hline 13 & $\begin{array}{l}\text { I prefer eLearning because I can join sessions } \\
\text { whenever I want }\end{array}$ & 61 & 41 & 68 & 46 \\
\hline 16 & $\begin{array}{l}\text { I prefer eLearning for the variety of activities, tasks } \\
\text { and assessments...etc. }\end{array}$ & 108 & 73 & 26 & 18 \\
\hline 17 & In eLearning I can express my ideas and freely & 119 & 80.4 & 16 & 11 \\
\hline
\end{tabular}




\begin{tabular}{|l|l|c|c|c|c|}
\hline 19 & $\begin{array}{l}\text { I prefer eLearning because I can participate while } \\
\text { unobserved by others }\end{array}$ & 98 & 66 & 26 & 18 \\
\hline 20 & $\begin{array}{l}\text { I prefer eLearning because I can follow sessions } \\
\text { while in different postures and positions: Iying, } \\
\text { sitting in the car...etc. }\end{array}$ & 113 & 76.4 & 12 & 8.1 \\
\hline 27 & $\begin{array}{l}\text { I prefer eLearning because unlike the traditional } \\
\text { mode, I can get recorded copies of the lectures }\end{array}$ & 138 & 93 & 10 & 7 \\
\hline
\end{tabular}

To test Hypothesis ' $B$ ', which is related to gender differences in the dimension of the reasons for preferring eLearning to face-toface or vice versa, an independent-samples t-test was conducted for this purpose. The result showed that there was no significant difference in scores for males $(M=50.53, S D=8.5)$ and females $(M=52.5, S D=9.8 ; t(143)=1.216-p=.23$, twotailed).

Question 3: What are the problems of eLearning as perceived by the participants? Table 7 presents the descriptive statistics: frequencies and percentages of the problems as perceived by the participants.

Table 7: Problems with eLearning

\begin{tabular}{|l|l|l|l|l|l|}
\hline \multirow{2}{*}{$\begin{array}{l}\text { Item } \\
\text { N0 }\end{array}$} & \multicolumn{1}{|c|}{ Item } & \multicolumn{2}{l|}{ Agree } & \multicolumn{2}{l|}{ Disagree } \\
\cline { 5 - 7 } & & Freq. & $\%$ & Freq. & $\%$ \\
\hline 10 & In eLearning, I face internet connection problems & 52 & 35 & 66 & 45 \\
\hline 11 & $\begin{array}{l}\text { In eLearning, I face problems in using the Technology like } \\
\text { laptops and mobiles }\end{array}$ & 35 & 24 & 93 & 63 \\
\hline 18 & Using eLearning troubles my sight & 48 & 33 & 73 & 49 \\
\hline 22 & $\begin{array}{l}\text { In eLearning, the low achievers get higher grades than the high } \\
\text { achievers }\end{array}$ & 26 & 18 & 90 & 61 \\
\hline 23 & In eLearning cheating is common & 19 & 13 & 96 & 65 \\
\hline 28 & $\begin{array}{l}\text { In eLearning low achievers and high achievers are treated } \\
\text { equally with respect to evaluation }\end{array}$ & 31 & 21 & 94 & 64 \\
\hline
\end{tabular}

Coming to hypothesis $C$, which states that there was no difference between males and females regarding the problems with eLearning, an independent-samples t-test was conducted for this purpose. The result showed that there was no significant difference in scores for males $(M=14.9, S D=4.3)$ and females $(M=15.7, S D=4.2 ; t(145)=1.06 p=.29$, two-tailed). As shown, the value is $p>.05$ so no difference was found between males and females regarding their views on problems with elearning.

\section{Discussion}

Question 1 is about which mode of learning was preferred. As the results have revealed in the first Dimension, the participants have opted for eLearning mode as their preferred one rather than the traditional face-to-face mode. In other words, the students have an appositive attitude toward elearning. This result is supported by other studies Naghavi (2007). If we go over the individual items for the first dimension in Table 5, we can see that in Item1, a majority of $100(67.6 \%)$ said the eLearning mode was better than the face-to-face one. This result is confirmed by other studies like those by Ismaili (2021) and Law and Huang (2011). In both studies students show positive attitudes to elearning. However, in the latter one, males show a more positive attitude than females. To proceed to the next item, the participants say that they learnt better through this mode with a total agreement of $90(61 \%)$. However, when asked if they still would prefer elearning even though they get low grades, only about $58(39.2 \%)$ agreed against 61(41.2\%) who disagreed. Now, though the difference between those who agreed and those who did not was small, this result is still indicative that grades are important for this type of student. It can mean that if the students get lower grades in their eLearning performance, they might change their minds about the preferred mode of learning _ eLearning. It is worth mentioning that these students often get high grades in online examinations. This has become common at least with this particular type of students. When asked about their opinion if instructors preferred eLearning, a majority $72(52.7 \%)$ said that instructors preferred elearning to face-to-face. How did they know that? Many instructors ( $\mathrm{am}$ one of them) did not like full online instruction because they were under big pressure and heavy load with so many requirements to cope with, which were more than they could tolerate. Therefore, the students just thought that instructors preferred elearning just as they themselves did. This means, if the students preferred eLearning, then all instructors would do the same. So, they thought. However, with EFL university instructors, a high level of positive satisfaction was found in the Saudi context (Alhudaithy, 2021), but not at the 
University of Bisha. Instructors' satisfaction at the University of Bisha needs to be investigated, however. When asked about students' involvement in elearning activities, agreement among the participants was the highest; About 110 (74.3\%) of the participants claimed that they were more involved in eLearning than they were in face-to-face. Our observations as instructors belied this claim. It was observed the opposite. Students were more reluctant to take active parts except for those who were already active in face-to-face classes. Not only that, but students used to join a session and then, after a few minutes, leave the session while their names appear in the list as the present, but in reality, they are not. Participants showed some contradictions in their responses in Items 26 and 29. While in Item 26 most of the participants agreed that eLearning should be used only in crises and emergencies, in Item 29 they changed their minds and said full elearning should be used in future. However, it could be understood that while complete elearning must be used in emergencies, they did not object to its use in the future.

Question 1: The question which was about which mode of learning the participants preferred was therefore answered that they preferred eLearning, and the related Hypothesis 'A' about if there was a significant difference between males and females in their preference of the mode of learning was accepted because no significant difference was found.

Question 2: Moving to the second Dimension about the reasons for preferring eLearning, all responses are given in Table 6. One reason the participants gave (Item 2) was their unwillingness to attend classes in college with a total agreement 63(43\%) against 23 (16\%). This response was enhanced more by Item 3 in which a majority of the participants $85(57.4 \%)$ said they preferred elearning because examination was not held at college. So, more students preferred to take eLearning from home rather than going to college. The reasons for this are simple; Instead of wasting time, (Item 4) cost, and effort (Item 5) it is far much better to stay at home and just join the sessions whenever one wants (Item13), and the way one likes (Items $8 \& 20$ ). The advantages of saving time, cost and effort was also reported in some earlier studies like that byAyden \&Tasci, 2005; Schreurs et al., 2008; Abed, (2020). The flexibility of eLearning (Mohmmed \&Mohamed, 2021) ; Abduljawad, Ahmad, Jaber, Al Thunaibat, Maria, Khasawneh, \& Hijazi, 2020) was one feature that attracted the students to this type of learning. Moreover, taking examinations in the college classroom means making things difficult for the students because they cannot practice cheating and similar malpractices. When asked if they preferred elearning because they were somehow put under pressure to participate (Item 6), a majority of 96(65\%) disagreed.

For them, participation was not a major reason for preferring eLearning. This point was also implied in Item 19, in which they said they preferred elearning because they did not want to be watched by others as the case was in the classroom. However, this does not mean that they take an active part in elearning sessions. Only the highly motivated students and those who were usually active in face-to-face classes showed a tendency to participate in eLearning sessions. In Item7, more participants $72(49 \%)$ against $57(39 \%)$ said they preferred elearning because they got higher grades. Though it was difficult to say that openly, yet more participants did not hesitate to say what they believed that grade meant a lot to them. During elearning sessions, it was observed that students liked to participate by writing rather than by speaking. This was emphasized in Item12; as expected, a big majority $122(82.4 \%)$, against $17(12 \%)$ said they preferred elearning because of the advantage of participating through writing in the chat tool. This was observed with many students and with females in particular who used to participate by writing rather than by speaking. In Item 16 more than two-thirds of the participants 108 (73\%) against 26 (18\%) said they preferred eLearning because of the variety of activities and assessments methods. The students were right, as there were different kinds of activities besides online sessions with the use of PowerPoints; they could have You Tubes, different files including pdf ones, eBooks, different links to relevant websites, forums, discussion board tasks etc. Assessment methods were various, so besides assignments, quizzes and tests, they could give presentations, do graded board discussions, use wikis, blogs, and the like. Item 17 is one of the items that got the highest percentage $119(80.4 \%)$ against $16(11 \%)$. Here, the participants stated that they preferred eLearning because they could freely express their own feelings and ideas without fear of being watched by others (Item19). This was expected as from contact with many of these students, we came out with the conclusion that they did not want to be seen by others for fear of making mistakes or because they felt shy. One of the reasons they gave was that they preferred elearning because they had recorded copies of the sessions (Item27). This is the highest recorded response in this category $138(93 \%)$ against only $10(7 \%)$. This advantage is not available with the traditional face-to-face mode. However, while it can be an advantage, it may turn out to be a disadvantage because having a recorded session ready, means they can escape sessions, hoping to watch them later or only at examinations time.

Question 2: This question was about whether there was a difference between males and females regarding why the participants preferred eLearning. That question was answered positively as above. The related Hypothesis ' $\mathrm{B}$ ' was accepted that there was no significant difference between male and female participants. Both genders preferred elearning for the same reasons and almost equally. 
Question 3: The third question deals with problems and difficulties of eLearning (Dimension 3). As seen in Table 7, there are six items; less than one-half of the participants in Item10,66(45\%) said they faced difficulties with an Internet connection and this was against 52(35\%) who did not face such difficulties. These kinds of difficulties are also mentioned in Mahyoob's study (2020), and they are not peculiar to only the Saudi context but to other contexts as well (Zalat et al., 2021 \& ElSaheli-Elhage, 2021 ). Problems with Internet connection usually happen if the weather is bad, or if Internet speed for unknown reasons is slow or if a student happens to be in a remote area not covered with the Internet service. However, this was not common; it happened only with a few students, and if they were truthful, some students used Internet dis-connectivity as a pretext for their absence or joining sessions late. The next Item (11) is about the problem with using technology devices for eLearning; here, only 35(24\%) said they had such difficulties against 93(63\%) who did not face difficulties in using technology devices. So, most of the students did not have that kind of problems. Nevertheless, the number of those who had such difficulties should not be underestimated. This means these students might not get what others did. However, such difficulties are also found even in developed countries like the USA (EISaheli-Elhage, 2021). This is normal, as Saudi students are quite familiar with different types of technology devices. In Item18 about 48(33\%) stated that, in eLearning, they suffered sight problems. This was a result of staying a long time in front of these devices following different sessions and doing tasks and other activities. This problem was also found with some schoolchildren who turned to wear sight glasses after the deterioration of their sight due to long hours studying online. The participants did not agree (Item 22) that in eLearning, low achievers got high marks just as high achievers or even better. Only 26(18\%) agreed with this statement against 90(61\%) who did not. Those who agreed with the statement, we can guess, were those who used to be good achievers and who suffered in eLearning because lazy or slow working students got better grades than they did. One might question the reason behind the situation. The answer is 'cheating' as stated in Item 23. Again, most of the participants $96(65 \%)$ did not see that cheating is common in elearning. This is contrary to what has become a common phenomenon among online learners. Plagiarism and cheating are a kind of "academic dishonesty (Underwood, \& Szabo, 2003, p. 467). It has been reported that the "Internet is a valuable source for students engaging in "academic impropriety" (Jones, Ried, \& Bartlett, 2008, p.45). This is what happened with this type of students; they cheat in examinations and this explains why usual underachievers get higher grades than the good achievers. The students did not want to confess this "temptation" (Jones, Ried, \& Bartlett, 2008, p.45), and this denial is normal with young people of this age. It may be true to say that these students accept cheating as a legitimate act to achieve their goals (Underwood \& Szado, 2003). On the other hand, this tells us that Internet is not secure and this explains why instructors in the Arab World in particular have been cautious in giving examinations online (Abouchedid, \& Eid, 2004). The same happens with the last item in this category (Item 28), participants did not agree with the idea that high achievers were treated as equal to underachievers. Those who agreed made only 31(21\%) against 94(64\%). Again, as the high achievers in face-to-face classrooms are usually a minority so the majority of the participants in this study were against the statement.

Question 3: Here the question is whether there is a gender difference regarding problems with eLearning with its related Hypothesis ' $C$ ' that says there was no difference between male and female participants in their attitudes to the problems and difficulties with elearning. That hypothesis was accepted as no difference was found.

Thus, the three hypotheses of the three dimensions were accepted because no differences were found with respect to genders.

\section{Conclusions}

From what has been said in the previous pages, we come to the following conclusions:

1. The majority of the students preferred elearning to face-to-face mode.

2. The reasons expressed by the participants were many and most of which were that eLearning saves time, effort and cost; it is flexible and can be taken anywhere in any position. Activities and assessment methods vary. It suits the different personalities of the students, whether they are introverts and extroverts and so on. Getting high grades was also the reason for their preference for eLearning.

3. According to the participants, eLearning has many advantages; however, it is not free from some problems. Of these problems are those related to Internet connection and the use of technology.

4. Students disagreed with the issues related to cheating which seems to have some implications about their behaviors and personalities.

5. No differences were found between males and females in the three dimensions: preference of learning mode, the reasons for their choice and the problems with eLearning. All of the participants_ males and females_ have the same attitudes to eLearning.

\section{Recommendations}

1. To avoid the negative aspects of full eLearning mode, it is recommended that some kind of a mixture between eLearning and classroom-based learning is used. This form is known as blended learning. The adoption of this form is in agreement with what is suggested by researchers like Dalmolin et al. (2018). For these researchers and others, the suggested 
mode was found to improve learning and through which cheating, plagiarism, and other negative practices can somehow be controlled.

2. When there is no way but to use a full elearning mode, it is recommended that some mechanism be used to ensure that problems such as cheating and plagiarism are properly controlled.

\section{Suggestions}

Further research should be carried out to ascertain the negative aspects of eLearning regarding cheating, plagiarism, and how the undeserved students get better grades than those who deserve.

\section{References}

[1] Abduljawad, M., Ahmad, A., Jaber, K. M., Al Thunaibat, A., Maria, E. A., Khasawneh, A., \& Hijazi, H. (2020). Evaluating and adopting eLearning systems in Al-Zaytoonah University of Jordan. Int. J. Advance Soft Compu. Appl, 12(3), 82-101.

[2] Abed, A. Y. (2020). Measuring eLearning readiness of the students in Tishk International University. MECSJ, 29(45), 1-14.

[3] Abouchedid, K., \& Eid, G. M. (2004). E-learning challenges in the Arab world: revelations from a case study profile. Quality Assurance in Education 12(1), 15-27.

[4] Algahtani, A. (2011). Evaluating the effectiveness of the eLearning experience in some universities in Saudi Arabia from male students perceptions. (Doctoral Dissertation, Durham University) Durham Theses. 1-311.

[5] Alhudaithy, H. (2021). Exploring female academic perceptions and practices utilizing learning and communication technology in the Languages Faculty at King Khalid University in Saudi Arabia. (Thesis, 1-296, University of the West of England). Retrieved from https://uwerepository.worktribe.com/output/4755639.

[6] Al-Jubori, S. S., Al-Janabi, S. S., \& Kareem, H. A. (2021). Factors affecting e-leaners' ability to learn English as a foreign language (EFL) online: A literature review. Lark Journal for Philosophy, Linguistics and Social Sciences, 1(40), 1164-1178.

[7] Alqadah, F.H. (2021). Evaluating of eLlearning and its impact on the level of University students' satisfaction: A case. Islamic Univeristy Journal of Economic and Business Studies,29(1), 21-44.

[8] Al-rashidi, B.A.(2020). The impact of eLearning in improving self-learning skills in the students of education and communication technologies at Hail University. IUG Journal of Educational and Psychology Sciences, 28 (1), 141 -161.

[9] Al-Samarraie, H., Teng, B. K., Alzahrani, A. I., \& Alalwan, N. (2017). ELearning continuance satisfaction in higher education: A unified perspective from instructors and students. Studies in Higher Education, 43(11), 2003-2019. doi:10.1080/03075079.2017.1298088

[10] Arkorful, V., \& Abaidoo, N. (2015). The role of eLearning, advantages and disadvantages of its adoption in higher education. International Journal of Instructional Technology and Distance Learning, 12(1), 29-42.

[11] Ayden, C. H., \& Tasci. D. (2005). Measuring readiness for eLearning: Reflections from an emerging country. Educational Technology \& Society, 8 (4), 244-257.

[12] Dalmolin, A. C., Mackeivicz, G. A. O., Pochapski, M. T., Pilatti, G. L., \& Santos, F. A. (2018). Learning styles preferences and e-learning experience of undergraduate dental students. Revista de Odontologia da UNESP, 47(3), 175-182. doi:10.1590/1807-2577.05118

[13] ElSaheli-Elhage, R. (2021). Access to students and parents and levels of preparedness of educators during the COVID-19 emergency transition to e-learning. International Journal on Studies in Education, 3(2), 61-69

[14] Fageeh, A. I. (2011). EFL students' readiness for eLearning: Factors influencing e-learners' acceptance of the Blackboard in a Saudi university. The Jalt Call Journal, 7(1), 19-42. https://doi.org/10.29140/jaltcall.v7n1.106

[15] Ismaili, Y. (2021). Evaluation of students' attitude toward distance learning during the pandemic (Covid-19): a case study of ELTE university. On the Horizon19(1), 17-30. https://doi.org/10.1108/OTH-09-2020-0032

[16] Jones, K. O., Reid, J., \& Bartlett, R. (2008). ELearning and cheating. Communication \& Cognition, 41 (1),45-61.

[17] Kaur, N., Dwivedi, D., Arora, J., \& Gandhi, A. (2020). Study of the effectiveness of eLearning to conventional teaching in medical undergraduates amid covid-19 pandemic. National Journal of Physiology, Pharmacy and Pharmacology, 10(7),563-366. doi:10.5455/njppp.2020.10.04096202028042020

[18] Kholifah, N., Sudira, P., Rachmadtullah, R., Nurtanto, M., \& Suyitno, S. (2020). The effectiveness of using blended learning models against vocational education student learning motivation. International Journal, 9(5),7964-7968, 2020, doi: 10.30534/ijatcse/2020/151952020

[19] Liaw, S. S., \& Huang, H. M. (2011, September). A study of investigating learners attitudes toward e-Learning. In 5th International Conference on Distance Learning and Education 12, 28-32.

[20] Mahyoob, M. (2020). Challenges of eLearning during the Covid-19 pandemic experienced by EFL learners. Arab World English Journal, 11(4), 351-362. doi:10.24093/awej/vol11no4.23

[21] Marc, J. R. (2002). ELarning strategies for delivering knowledge in the digital age. Internet and Higher Education, 5, 185-188.

[22] Mohmmed, R. S. \& Mohamed, H.N. (2021). Determiners of agricultural eLearning from the point of view of students: A filed study in the Agricultural College, Ain Shmas University in the Light of Corna Crisis. Journal of Agricultural Economics and Social Sciences, 12(2), 39-48. doi:10.21608/jaess.2021.155476

[23] Naghavi, M. A. (2007). Study of teachers and students Attitude toward eLearning: Surveying in Iran's eLearning universities. Quarterly journal of research and planning in higher education, 13(1), 157-76.

[24] Omar, N. D., Hassan, H., \& Atan, H. (2012). Student engagement in online learning: Learners' attitude toward e-mentoring. Procedia - Social and Behavioral Sciences, 67, 464-475. doi:10.1016/j.sbspro.2012.11.351

[25] Pallant, J., \& Manual, S. S. (2010). A step by step guide to data analysis using SPSS. Berkshire UK: McGraw-Hill Education .

[26] Sandars, J., \& Langlois, M. (2005). ELearning and the educator in primary care: Responding to the challenge. Education for Primary Care, 16(2), 129-133.

[27] Schreurs, J., Ehlers, U. D., \& Sammour, G. (2008). ELearning readiness analysis (ERA): An e-health case study of eLarning readiness. International Journal of Knowledge and Learning, 4(5). doi:10.1504/ijkl.2008.022066 
[28] Sir elkhatim, A., Ahmed, R. Awad, S. \& Zobaier, A. (2021). The effect of eLearning on enhancing students' knowledge from the viewpoint of the female community college students in Khamis Mushait. Journal of Human and Social Sciences, 4(1), 426-452.

[29] Slagter van Tryon, P. J., \& Bishop, M. J. (2012). Evaluating social connectedness online: The design and development of the social perceptions in learning contexts instrument. Distance Education, 33(3), 347-364. doi:10.1080/01587919.2012.723168

[30] Suerni. (2021). The effect of eLearning on students' learning at the varsity Level. KnE Social Sciences, 5(4), 622-628. doi:10.18502/kss.v5i4.8717

[31] Sukendro, S., Habibi, A., Khaeruddin, K., Indrayana, B., Syahruddin, S., Makadada, F. A., \& Hakim, H. (2020). Using an extended Technology Acceptance Model to understand students' use of eLearning during Covid-19: Indonesian sport science education context. Heliyon, 6(11), 1-9. doi:10.1016/j.heliyon.2020.e05410

[32] Swanson, A., Davis, B., Parks, O., Atkinson, S., Forde, B., Choi, K., \& Washington, V. (2015). Student engagement, e-connectivity, and creating relationships in the online classroom: emerging themes. International Journal of Instructional Technology and Distance Learning, 12(1), 6672.

[33] Tarhini, A., Hone, K., \& Liu, X. (2013). Factors affecting students' acceptance of eLearning environments in developing countries: A structural equation modeling approach. International Journal of Information and Education Technology, 3(1), 54-59. doi:10.7763/ijiet.2013.V3.233

[34] Tessema, M. T., Ready, K., \& Yu, W. (2012). Factors affecting college students' satisfaction with major curriculum: Evidence from nine years of data. International Journal of Humanities and Social Science, 2 (2), 34-44. https://www.researchgate.net/publication/271077752

[35] Underwood, J., \& Szabo, A. (2003). Academic offences and eLearning: Individual propensities in cheating. British Journal of Educational Technology, 34(4), 467-477.

[36] Wheeler, K. (2012). The corporate university workbook: Launching the 21st century learning organization. John Wiley \& Sons.

[37] Zalat, M.M., Hamed M.S., \& Bolbol, S.A. (2021). The experiences, challenges, and acceptance of elearning as a tool for teaching during the COVID-19 pandemic among university medical staff. PLos One 16(3): e0248758. https://doi.org/10.1371/ journal.pone.0248758 